\title{
KORBAN KEJAHATAN DAN KEADILAN RESTORATIF DI INDONESIA
}

\author{
Oleh \\ Fransiska Novita Eleanora \\ Fakultas Hukum Universitas Mpu Tantular, Jakarta \\ Email: vita_eleanor@yahoo.com
}

\begin{abstract}
Victims of crime are those who are oppressed for they fail to get the justice they deserve. One of the issues on the matter is the reasonable compensation when the crime affecting them results in permanent disablement or even death. This research is to study whether or not the compensation amount as stipulated in KUHAP has met the sense of justice. The method used is library research. The findings reveal that the compensation amount given to victims of crime has not met the sense of justice, especially restorative justice, which means that the victims have not received justice they deserve.
\end{abstract}

Keywords: Crime, Victims of Crime, Restorative Justice

\begin{abstract}
Abstrak
Korban kejahatan merupakan orang yang tertindas, dikarenakan dalam pemenuhan hak-haknya seringkali tidak mendapatkan keadilan seperti yang diharapkan. Salah satunya adalah berkaitan dengan ganti rugi yang layak yang di dapatkan si korban kejahatan manakala cacat bahkan meninggal dunia. Tujuan tulisan ini adalah untuk mengetahui apakah ganti kerugian yang tercantum dalam KUHAP sudah memenuhi rasa keadilan terhadap korban kejahatan atau tidak. Sedangkan metode penelitian adalah studi pustaka, hasilnya adalah bahwa ganti kerugian yang di dapat oleh korban kejahatan belum memenuhi rasa keadilan, khususnya keadilan restorasi, artinya dalam pemenuhan hak-hak korban belum terpenuhinya keadilan yang merupakan bagian dari hak utama korban kejahatan.
\end{abstract}

Kata Kunci: kejahatan, korban kejahatan, keadilan restoratif

\section{PENDAHULUAN}

Masalah korban kejahatan tentunya tidak terlepas dari kejahatan itu sendiri yang memang merupakan bagian dari kehidupan manusia. Pelaku dan korban bagaikan 2 (dua) sisi mata uang, karena pada umumnya orang tidak dapat memikirkan adanya kejahatan disitu maka muncullah korban. Ketika tindak pidana terjadi, pihak yang secara langsung mengalami penderitaan adalah korban, 
tindak pidana yang terjadi dapat menciptakan situasi dan kondisi yang menyulitkan bagi korban untuk hidup sebagai warga masyarakat seperti sedia kala.

Hilang atau rusaknya harta benda atau cacatnya si korban jelas akan mengurangi kemampuan korban untuk menggapai tujuan hidupnya, demikian pula dengan trauma psikis dan stigma negatif yang dialami korban. Bahkan ketika proses peradilan untuk meminta pertanggungjawaban dijalankan, korban yang dihadapkan sebagai saksi seringkali masih di hadapkan pada kesulitan yang lain untuk mempersiapkan mental, fisik, waktu dan keuangan untuk datang ke pengadilan

Perlindungan terhadap korban kejahatan, adalah upaya preventif maupun represif yang dilakukan, baik oleh masyarakat meupun pemerintah (melalui aparat penegak hukumnya), seperti pemberian perlindungan/pengawasan dari berbagai ancaman yang dapat membahayakan nyawa korban, pemberian bantuan medis, maupun hukum secara memadai, serta besarnya ganti kerugian yang diberikan kepada korban kejahatan akibat tindak pidana yang terjadi, proses pemeriksaaan dan peradilan yang fair terhadap pelaku kejahatan, yang pada dasarnya merupakan salah satu perwujudan dari perlindungan hak asasi manusia serta instrument penyeimbang. ${ }^{1}$

Hukum dibuat oleh penguasa untuk ditegakkan, dan bertujuan untuk menjaga ketertiban, keamanan dan kedamaian dalam masyarakat, sehingga masyarakat menjadi aman dan tenteram. Sehingga tujuan hukum mengarah kepada sesuatu yang hendak dicapai serta meningkatkan kebahagiaan dengan cara melarang perbuatan-perbuatan yang mendatangkan sengsara. Suatu perbuatan yang dapat dipidana manakala perbuatan tersebut benar-benar dianggap merugikan individu atau kelompok tertentu.

Fungsi pemerintah adalah meningkatkan kebahagiaan masyarakat dengan memidana barangsiapa yang melakukan perbuatan yang melanggar prinsip utility. Prinsip utility dalam menentukan perbuatan-perbuatan apa saja yang

${ }^{1}$ G. Widiartana, Viktimologi Perspektif Korban Dalam Penanggulangan Kejahatan, (Yogyakarta: Universitas Atmajaya, 2009), hal. 41. 
dilarang, banyak perbuatan-perbuatan yang diatur oleh hukum pada masa ia hidup harusnya dipandang sebagai perbuatan dalam ruang lingkup pergaulan social yang apabila perbuatan itu dipandang salah cukup diberi sanksi teguran atau reaksi publik yang lain yang bukan merupakan sanksi hukum. ${ }^{2}$

Dengan melihat pendahuluan diatas maka tujuan penulisan makalah ini adalah untuk mengetahui apakah hak-hak korban kejahatan sudah memenuhi rasa keadilan.

\section{PEMBAHASAN}

\section{Kejahatan}

Kejahatan didefinisikan sebagai setiap pelanggaran terhadap perbuatan yang dilarang undang-undang pidana, penjahat adalah setiap orang yang melakukan kejahatan. Kejahatan dipandang sebagai hasil pilihan bebas dari individu dalam menilai untung ruginya melakukan kejahatan.

Oleh karena itu, secara rasional, tanggapan yang diberikan oleh masyarakat terhadap hal tersebut adalah dengan meningkatkan kerugian yang harus dibayar dan menurunkan keuntungan yang diperoleh dari kejahatan agar orang-orang tidak memilih untuk melakukan kejahatan.

Secara etimologi kejahatan adalah bentuk tingkah laku yang bertentangan dengan moral kemanusiaan, kejahatan merupakan suatu perbuatan atau tingkah laku yang sangat ditentang oleh masyarakat dan paling tidak disukai oleh rakyat.

Van Bemmelen merumuskan kejahatan adalah tiap kelakuan yang tidak bersifat susila dan merugikan, yang menimbulkan begitu banyak ketidaktenangan dalam suatu masyarakat tertentu, sehingga masyarakat itu berhak untuk mencelanya dan menyatakan penolakannya atas kelakukan itu dalam bentuk nestapa dengan sengaja diberikan karena kelakuan tersebut.

Jika dikaitkan dengan kejahatan-kejahatan yang terdapat dalam Kitab Undang-Undang Hukum Pidana (KUHP), adalah perumusan kejahatan dalam

${ }^{2}$ Peter Mahmud Marzuki, Pengantar Ilmu Hukum, (Jakarta: Kencana Prenada Media Group, 2008), hal . 23-28 
bentuk perbuatan yang memenuhi ketentuan Kitab Undang-Undang Hukum Pidana.

Sekalipun perumusan kejahatan sangat beragam namun pada intinya memiliki kesamaan unsur, dengan mengacu pada pendapat Kimball, unsur-unsur kejahatan itu adalah :
a. Pelaku
b. Kesalahan
c. Penyebab
d. Membahayakan
e. Diatur dalam suatu aturan
f. Akibat perbuatannya dikenai sanksi

Pada awalnya, kejahatan hanyalah merupakan "cap" yang diberikan masyarakat pada perbuatan-perbuatan yang dianggap tidak layak atau bertentangan dengan norma-norma atau kaidah-kaidah yang berlaku dalam masyarakat. Dengan demikian, ukuran untuk menentukan apakah suatu perbuatan merupakan suatu kejahatan atau bukan adalah "apakah masyarakat secara umum akan menderita kerugian secara ekonomis serta perbuatan tersebut secara psikologis merugikan sehingga dimasyarakat muncul rasa tidak aman dan melukai perasaan $^{3}$

Di satu sisi kejahatan dan ciri-ciri pelaku ditentukan oleh bagaimana undang-undang disusun dan dijalankan, Misalnya, apabila sebagian besar pelaku kejahatan adalah orang-orang yang miskin, maka bukan kemiskinan yang merupakan sebab kejahatan, akan tetapi karena bentuk-bentuk tindakan yang dilakukan oleh orang-orang miskin lebih banyak ditunjuk oleh undang-undang sebagai kejahatan dan dalam bekerjanya hukum maka undang-undang seperti inilah yang lebih banyak dijalankan.

Ini berarti bahwa kita tidak dapat memahami kejahatan semata-mata dengan mempelajari penjahat ("resmi"), akan tetapi harus dilihat dalam konteks

3 Didiek M. Arief Mansyur dan Elisatris Gultom, Urgensi Perlindungan Korban Kejahatan, (Jakarta: Rajawali Pers, na), hal. 55-57. 
keseluruhan proses kriminalisasi, yakni proses yang mendefinisikan orang dan tindakan tertentu sebagai kejahatan, hubungan antara kejahatan dengan proses kriminalisasi secara umum dinyatakan dengan digunakannya konsep "penyimpangan" dan reaksi social, untuk dapat memahami kejahatan, perlu dipelajari seluruh proses kriminalisasi, dalam arti proses-proses yang mempengaruhi pembentukan undang-undang yakni dijadikannya perbuatan tertentu sebagai tindak pidana maupun dalam bekerjanya hukum yakni prosesproses yang menjadikan orang-orang tertentu sebagai penjahat. ${ }^{4}$

Kejahatan dipandang sebagai bagian dari "penyimpangan social” dalam arti bahwa tindakan yang bersangkutan "berbeda" dari tindakan-tindakan yang dipandang sebagai norma atau biasa di masyarakat, dan terhadap tindakan menyimpang tersebut diberikan reaksi social yang negatif, dalam arti secara umum masyarakat memperlakukan orang-orang tersebut sebagai berbeda dan jahat. $^{5}$

\section{Korban Kejahatan}

Berbagai pengertian korban banyak dikemukakan baik oleh para ahli maupun bersumber dari konvensi-konvensi international yang membahas mengenai korban kejahatan, sebagian diantaranya adalah sebagai berikut :

a. Arief Gosita

Menurutnya, korban adalah mereka yang menderita jasmaniah dan rohaniah sebagai akibat tindakan orang lain yang mencari pemenuhan kepentingan diri sendiri atau orang lain yang bertentangan dengan kepentingan hak asasi pihak yang dirugikan.

b. Muladi

Korban (victims) adalah orang-orang yang baik secara individual maupun kolektif telah menderita kerugian, termasuk kerugian fisik atau mental emosional, ekonomi atau gangguan substansial terhadap hak-haknya yang

\footnotetext{
${ }^{4}$ I.S Susanto, Kriminologi, (Yogyakarta: Genta Publishing, 2011), hal. 85.

5 Ibid., hal. 55.
} 
fundamental, melalui perbuatan atau komisi yang melanggar hukum pidana di masing-masing negara, termasuk penyalahgunaan kekuasaan.

c. Deklarasi PBB Dalam The Declaration of Basic Principles of Justice for Victims of Crime and Abuse of Power yang dimuat dalam Resolusi Majelis Umum Perserikatan Bangsa-Bangsa No. 40/34 tanggal 29 November 1985

Korban sebagai orang yang secara individual maupun kelompok telah menderita kerugian, termasuk cedera fisik maupun mental, penderitaan emosional, kerugian ekonomi, atau perampasan yang nyata terhadap hak-hak dasarnya, baik karena tindakan (by act) mamupun karena kelalaian (by omission).

Dengan mengacu pada pengertian-pengertian korban di atas, dapat dilihat pada bahwa korban pada dasarnya tidak hanya orang perorangan atau kelompok yang secara langsung menderita akibat dari perbuatan-perbuatan yang menimbulkan kerugian / penderitaan bagi diri / kelompoknya, bahkan lebih luas lagi termasuk didalamnya keluarga dekat atau tanggungan langsung dari korban dan orang-orang yang mengalami kerugian ketika membantu korban mengatasi penderitaannya atau untuk mencegah viktimisasi.

Stanciu menjelaskan korban dalam arti luas adalah orang yang menderita dari ketidakadilan, dan ada 2 (dua) sifat yang mendasar (melekat) dari korban tersebut, yaitu suffering (penderitaan) dan injustice (ketidakadilan). Dalam kasus kejahatan konsep tentang korban seharusnya tidak saja dipandang dalam pengertian juridis, sebab masyarakat sebenarnya selain dapat menciptakan penjahat, juga dapat menciptakan korban. Seorang korban ditempatkan pada posisi sebagai akibat kejahatan yang dilakukan terhadapnya baik dilakukan secara individu, kelompok ataupun negara.

Konsep kejahatan dan siapa yang menjadi korban kejahatan adalah pangkal tolak untuk menjelaskan bagaimana posisi hukum korban. Ada 2 (dua) konsep kejahatan, Pertama, kejahatan dipahami sebagai pelanggaran terhadap negara atau kepentingan publik yang dipresentasikan oleh instrument demokratik 
negara. Kedua, kejahatan dipahami sebagai pelanggaran terhadap kepentingan masyarakat, negara dan esensinya juga melanggar kepentingan pelakunya sendiri. ${ }^{6}$

Dengan alur pikiran bahwa kejahatan yang menimbulkan korban merupakan hasil dari konstruksi sosial, maka dalam memahami pengertian korban dan cakupannya tidak boleh dilupakan bahwa itu semua juga merupakan hasil konstruksi sosial. Jadi, pengertian korban dan luas cakupannya dan juga merupakan konstruksi sosial, dan demikian ia akan sangat tergantung pada pemahaman orang / masyarakat pada viktimisasinya itu sendiri.

Perbuatan yang dikonstruksikan dalam undang-undang sebagai kejahatan secara jelas akan menunjukkan spesifikasi dari korbannya, hal ini menunjukkan bahwa pada umumnya orang dianggap sebagai korban kejahatan apabila ia menjadi obyek atau sasaran kejahatan yang disebut dalam undang-undang, Contohnya : seseorang menjadi korban pencurian apabila barang miliknya diambil dan dimiliki secara melawan hukum oleh orang lain (Pasal 362 KUHP), demikian juga orang menjadi korban penganiayaan apabila badannya dengan sengaja disakiti atau dicederai oleh orang lain (Pasal 351 KUHP).

Akibat-akibat tidak mengenakkan, baik kerugian, luka-luka, bahkan mati, apabila tidak disebabkan oleh perbuatan yang dirumuskan dalam undangundang sebagai tindak pidana, maka orang yang mengalami akibat-akibat tersebut tidak dapat disebut sebagai korban tindak pidana, padahal kita tahu bahwa masih banyak pihak yang mengalami kerugian, kehilangan, atau penderitaan akibat dari perbuatan-perbuatan tertentu yang tidak dirumuskan sebagai tindak pidana dalam undang-undang, missal : upah sangat rendah yang diterima oleh buruh atau perlindungan keselamatan kerja yang tidak sepadan dengan resiko pekerjaan.

\section{Hak dan Kewajiban korban}

Berkaitan dengan korban kejahatan, perlu dibentuk suatu lembaga yang khusus menanganinya. Namun, pertama-tama perlu disampaikan terlebih dahulu

\footnotetext{
${ }^{6}$ Siswanto Sunarso, Viktimologi Dalam Sistim Peradilan Pidana, (Jakarta: Sinar Grafika,
} 2012), hal. 42-43. 
suatu informasi yang memadai mengenai hak-hak apa saja yang dimiliki oleh korban dan keluarganya, apabila dikemudian hari mengalami kerugian atau penderitaan sebagai akibat dari kejahatan yang menimpa dirinya.

Hak merupakan sesuatu yang bersifat pilihan (optional), artinya bias diterima oleh pelaku bisa juga tidak, tergantung kondisi yang mempengaruhi korban baik yang sifatnya internal maupun eksternal.

Sekalipun demikian tidak sedikit korban atau kelauarganya mempergunakan hak-hak yang telah disediakan. Ada beberapa hak umum yang disediakan bagi korban atau keluarga korban kejahatan, yang meliputi :

a. Hak untuk memperoleh ganti kerugian atas penderitaan yang dialaminya, pemberian ganti kerugian ini dapat diberikan oleh pelaku atau pihak lainnya, seperti negara atau lembaga khusus yang dibentuk untuk menangani masalah ganti kerugian korban kejahatan.

b. Hak untuk memperoleh pembinaan dan rehabilitasi

c. Hak untuk memperoleh perlindungan dari ancaman pelaku

d. Hak untuk memperoleh bantuan hukum

e. Hak untuk memperoleh kembali harta miliknya

f. Hak untuk memperoleh akses atas pelayanan medis

g. Hak untuk diberitahu bila pelaku kejahatan akan dikeluarkan dari tahanan sementara, atau bila pelaku buron dari tahanan

h. Hak untuk memperoleh informasi tentang penyidikan polisi berkaitan dengan kejahatan yang menimpa korban

i. Hak atas kebebasan pribadi / kerahasiaan pribadi, seperti merahasiakan nomor telepeon atau identitas korban lainnya.

Deklarasi Perserikatan Bangsa-Bangsa No. 40/A/Res/34 tahun 1985 juga telah menetapkan beberapa hak korban (saksi) agar lebih mudah memperoleh akses keadilan, khususnya dalam proses peradilan, yaitu :

a) Rasa hormat dan pengakuan

b) Menerima informasi dan penjelasan tentang perkembangan kasus

c) Memberikan informasi

d) Memberikan bantuan yang tepat 
e) Perlindungan privasi dan keamanan fisik

f) Restitusi dan kompensasi

g) Untuk akses ke mekanisme sistem peradilan

Sekalipun hak-hak korban kejahatan telah tersedia secara memadai, mulai dari hak atas bantuan keuangan (finansial) hingga atas pelayanan medis dan bantuan hukum, tidak berarti kewajiban dari korban kejahatan diabaikan eksistensinya karena melalui peran korban dan keluarganya diharapkan penanggulangan kejahatan dapat dicapai secara signifikan.

Untuk itu, ada beberapa kewajiban umum dari korban kejahatan, antara lain:

a. Kewajiban untuk tidak melakukan upaya main hakim sendiri / balas dendam terhadap pelaku (tindakan pembalasan)

b. Kewajiban untuk mengupayakan pencegahan dari kemungkinan terulangnya tindak pidana

c. Kewajiban untuk memberikan informasi yang memadai mengenai terjadinya kejahatan kepada pihak yang berwenang

d. Kewajiban untuk tidak mengajukan tuntutan yang terlalu berlebihan kepada pelaku

e. Kewajiban untuk menjadi saksi atas suatu kejahatan yang menimpa dirinya, sepanjang tidak membahayakan bagi korban dan keluarganya

f. Kewajiban untuk membantu berbagai pihak yang berkepentingan dalam upaya penaggulangan kejahatan

g. Kewajiban untuk bersedia dibina atau membina diri sendiri untuk tidak menjadi korban lagi. ${ }^{7}$

Di samping hak dan kewajiban diatas, maka ada juga model pendekatan yang dipakai berkaitan dengan hak-hak korban yakni :

${ }^{7}$ Ibid., hal. 56 
1) Model Hak-Hak Prosedural (procedural rights model or participatory) penekanan diberikan pada dimungkinkannya korban untuk memainkan peranan aktif dalam proses pemidanaan atau proses peradilan pidananya. Model Pendekatan semacam ini melihat korban sebagai subyek yang harus diberi hak-hak yuridis yang luas untuk mengejar dan menuntut kepentingankepentingannya. Dalam hal smacam ini korban diberi semacam hak untuk mengadakan tuntutan pidana atau paling tidak mempunyai peranan aktif untuk menentukan tuntutan pidana terhadap pelaku. Termasuk dalam model ini adalah hak untuk dihadirkan dan didengar disetiap tingkatan proses peradilan, karena kepentingannya terkait didalamnya. Bahkan ketika lembaga koreksi (lembaga pemasyarakatan) akan memberikan pelepasan bersyarat pada pelaku yang sudah dipidana, korban wajib dimintai pendapat itu. Pada akhirnya guna penyelesaian perkaranya itu, korban diberi hak untuk mengadakan perdamaian atau menggugat secara perdata.

2) Model Pelayanan (services model), perhatian terhadap korban ditekankan pada pemberian pelayanan yang didasarkan pada standar-standar baku yang sengaja diciptakan untuk itu. Program-program pelayanan yang diadakan dapat dibebankan kepada aparat peneak hukum, jenisnya pun beraneka ragam, mulai dari disediakannya ahki-ahli kejiwaan guna memulihkan kondisi psikis korban sampai disediakannya program restitutif guna mengembalikan kerugian yang diderita akibat menjadi korban tindak pidana. Dengan demikian, model kedua ini melihat korban sebagai obyek pelayanan oleh aparat penegak hukum. Pelaksanaan model kedua mensyaratkan penguasaan victimagogig, yaitu pengetahuan tentang efek-efek kejahatan terhadap korban serta cara-cara, baik yuridis, psikologis, social, dan lain sebagainya, untuk mengurangi pengaruhnya terhadap korban. ${ }^{8}$

\section{Keadilan Restoratif di Indonesia}

Kejahatan dianggap sebagai persoalan antara negara dan individu pelaku karena hukum negara telah dilanggar oleh pelaku, maka keadilan restoratif

\footnotetext{
${ }^{8}$ G. Widiartana, Op. Cit., hal. 56-58
} 
memandang kejahatan sebagai konflik antar individu, pertanggungjawaban pelaku dirumuskan sebagai dampak pemahaman terhadap perbuatannya serta untuk membantu memutuskan mana yang paling baik bagi penyelesaian tindak pidana dengan mempertimbangkan penderitaan atau kerugian korban.

Adapun nilai-nilai yang ingin dicapai melalui penyelenggaran peradilan pidana adalah :

a) Penyelesaian konflik yang mengandung muatan pemberian ganti kerugian dan pemulihan nama baik

b) Menciptakan rasa aman yang mengandung muatan perdamaian dan ketertiban.

Banyaknya ketentuan peraturan yang mengatur tentang ganti kerugian kepada korban kejahatan, seperti di dalam KUHAP yang mencerminkan perlindungan terhadap korban, pasal-pasal tersebut antara lain sebagai berikut : Pasal 80, Pasal 108 ayat (1), Pasal 133 ayat (1), Pasal 134 ayat (1), Pasal 160 ayat (1b), Pasal 98 ayat (1), Pasal 99, Pasal 100 ayat (1) dan pasal 101 KUHAP.

Dalam aturan pelaksanaan ini tidak disebut-sebut lagi tentang praperadilan yang mempunyai acaranya sendiri. Ini berarti acara pelaksanaan ganti kerugian dalam Pasal 95 ayat (3) dan (4) KUHAP ini hanya mengatur ganti kerugian yang berhubungan dengan perkara yang diajukan ke pengadilan negeri.

Sedangkan untuk Pasal 98-101 KUHAP, adalah pasal-pasal yang berkaitan dengan hak korban dalam menuntut ganti kerugian, mekanisme yang ditempuh adalah penggabungan perkara gugatan ganti kerugian pada perkara pidana, dan penggabungan tersebut merupakan acara yang khas dan karakteristik yang ada dalam isi ketentuan KUHAP. ${ }^{9}$

Perlindungan hukum terhadap korban selama ini didasarkan pada KUHP sebagai sumber hukum materiil, dengan menggunakan KUHAP sebagai hukum Acara, di dalam KUHAP lebih banyak diatur mengenai tersangka daripada mengenai korban, kedudukan korban dalam KUHAP tampaknya belum optimal dibandingkan dengan kedudukan pelaku. Hal ini dapat dijelaskan sebagai berikut :

${ }^{9}$ Andi Hamzah, Hukum Acara Pidana Indonesia, (Jakarta: Sinar Grafika, 2009), hal 15- 
Pertama, KUHP belum secara tegas merumuskan ketentuan secara konkret atau langsung memberikan perlindungan hukum terhadap korban.

Kedua, KUHP menganut aliran neoklasik yang antara lain menenerima berlakunya keadaan-keadaan yang meringankan bagi pelaku tindak pidana yang menyangkut, fisik lingkungan serta mental.

Rumusan pasal-pasal dalam KUHP cenderung berkutat pada rumusan tindak pidana, pertanggungjawaban, dan ancaman pidana. Demikian pula dimungkinkannya aspek-aspek yang meringankan pidana bagi pelaku tindak pidana bagi pelaku tindak pidana dengan pertanggungjawaban sebagian, didalam hal-hal yang khusus, (jiwa cacat, gila, dibawah umur, dan sebagainya).

Padahal korban merupakan salah satu aspek yang benar-benar mengalami penderitaan akibat perbuatan pelaku, perlindungan hukum bagi korban seharusnya diatur secara eksplisit dalam KUHP, begitu pula di dalam KUHAP pengeturan mengenai korban sama sekali termajirnalkan. KUHAP lebih banyak mengatur mengenai perlindungan terhadap tersangka, sedangkan perlindungan terhadap korban tidak dirumuskan secara lengkap. ${ }^{10}$

Definisi kejahatan untuk restorative justice menjadi penting mengingat dalam KUHP dan KUHAP orientasi kejahatan dirumuskan sebagai perbuatan yang terlarang yang diatur dalam UU dan diancam pidana bagi mereka yang melanggar larangan tersebut (Pasal 1 ayat (1) KUHP).

Proses penyidikan dirumuskan sebagai rangkaian tindakan penyidik dalam hal dan menurut cara yang diatur dalam undang-undang untuk mencari serta mengumpulkan bukti yang dengan bukti itu membuat terang tentang tindak pidana yang terjadi dan guna menemukan tersangkanya (Pasal 1 angka (2) KUHAP). Putusan pengadilan sebagai pernyataan hakim yang diucapkan dalam sidang pengadilan dapat berupa pemidanaan, bebas atau lepas dari segala tuntutan hukum (Pasal 1 angka (11) KUHAP).

\footnotetext{
${ }^{10}$ Siswanto Sunarso, Op. Cit., hal. 93-97.
} 
Morris menyatakan bahwa tanggapan terhadap kejahatan yang demikian dianggap sebagai peradilan dengan sistem konvensional yang memandang keadilan terutama secara ekslusif sebagai pelanggaran terhadap kepentingan negara (state law), dan tanggapan terhadap perlawanan tersebut dirumuskan oleh para professional yang mewakili negara.

Perbedaan mendasar restorative justice dengan peradilan menurut hukum acara KUHAP antara lain :

\begin{tabular}{|c|c|}
\hline Peradilan KUHAP & Terauma \\
\hline $\begin{array}{l}\text { 1. Mendasarkan pada kejahatan yang } \\
\text { dilakukan } \\
\text { 2. Menempatkan korban dalam } \\
\text { kedudukan yang sentral } \\
\text { 3. Tujuannya berpusat pada gagasan } \\
\text { bagaimana menghukum yang } \\
\text { bersalah dengan adil } \\
\text { 4. Retributive Justice } \\
\text { 5. Result in prison for the accused } \\
\text { 6. Ditentukan oleh professional hukum }\end{array}$ & $\begin{array}{l}\text { 1. Menunjuk pada kekeliruan (eror) } \\
\text { yang disebabkan karena } \\
\text { pelanggaran } \\
\text { 2. Menempatkan korban pada posis } \\
\text { yang sekunder } \\
\text { 3. Dasar tujuannya memberi kepuasan } \\
\text { yang dialami para pihak yang } \\
\text { terlibat dalam pelanggaran } \\
\text { 4. Restorative Justice } \\
\text { 5. Dialogue, negotiation, } \\
\text { resolution and } \\
\text { 6. Ditentukan oleh para pihak dalam } \\
\text { Conferencing }\end{array}$ \\
\hline
\end{tabular}

Kongres PBB ke XI di Bangkok, 18-25 April 2005 on Crime Prevention and Criminal Justice mengambil tema pokok upaya "responsif dan sinergis" dengan strategi yang kombinatif dalam cara-cara pencegahan kejahatan dan peradilan pidana (the main theme of Eleventh Congress would be "Synergies and responses : strategic alliances in crime prevention and criminal justice).

Sejalan dengan itu pula perlu kiranya kebijakan peradilan pidana Indonesia mengambil langkah-langkah responsif, sinergis dan kombinatif, yaitu 
selain cara-cara berdasarkan peradilan KUHAP, ditempuh pula peadilan restorative justice. ${ }^{11}$

Keadilan restoratif ini harus menekankan pada upaya pemulihan, ganti rugi dan rehabilitasi yang pemecahannya bisa mengikuti/ memilih pihak ketiga yang berkompeten dalam menangani masalah yang dihadapi serta tidak punya kepentingan apa-apa dalam masalah tersebut.

Sehingga mekanisme keadilan restorative antara, korban, pelaku dan pihak-pihak yang ditunjuk oleh pengadilan (sebagai pihak ke-3), duduk berhadapan dan bermusyawarah dalam hal mencari pemecahan masalah, besarnya ganti kerugian yang dibayarkan kepada korban jika sampai mengakibatkan cacat bahkan meninggal dunia, hal tersebut yang harus menjadi pemikiran, apakah tetap dibebankan kepada si pelaku ataukah negara yang membayar ganti rugi tersebut kepada pihak korban kejahatan

Hubungan yang manusiawi antara korban dengan pelanggar dan fokusnya pada dampak yang ditimbulkan oleh kejahatan pada semua pihak, bukan hanya pada korban tetapi juga pada korban dan pelanggar itu sendiri. Keadilan restorative bersendikan pada peranan korban kejahatan, masyarakat, negara dan pelanggar.

Pidana dan Pemidanaan menjadi bagian dari penyelesaian konflik dan menekankan pada perbaikan terhadap akibat kejahatan. Penyelesaian konflik melalui mediasi antara korban dengan pelaku melahirkan sikap yang kreatif, yaitu meminta pelaku secara personal memperanggungjawabkan tindakannya dengan menghadapi korban dan membuat kesepakatan mempromosikan keterlibatan masyarakat dan korban secara aktif dalam proses peradilan, dan mempertinggi kualitas keadilan dan yang dirasakan baik oleh korban maupun pelaku. ${ }^{12}$

Seperti yang dikatakan oleh Mudzakir, bahwa keadilan restorative dicirikan dengan beberapa Preposisi :

${ }^{11}$ Kuat Puji Prayitno, "Restorative Justice Untuk Peradilan Di Indonesia (Perspektif Yuridis Filosofis Dalam Penegakan Hukum In Concreto", Jurnal Dinamika Hukum, Vol. 12 No. 3 September 2012, hal. 415-416.

${ }^{12}$ Siswanto Sunarso, Op. Cit., hal. 4. 
1) Kejahatan adalah konflik antar individu yang mengakibatkan kerugian pada korban, masyarakat, dan pelaku itu sendiri.

2) Tujuan yang harus dicapai dari proses peradilan pidana adalah melakukan rekonsiliasi diantara pihak-pihak sambil memperbaiki kerugian yang ditimbulkan akibat kejahatan.

3) Proses peradilan pidana harus dapat memfasilitasi partisipasi aktif para korban, pelanggar, dan masyarakat ${ }^{13}$

Pada kasus tabrakan misalnya, korban seringkali tidak mendapat solusi atas masalah yang dihadapi, yaitu mendapatkan biaya rumah sakit dan penggantian atas biaya hidup karena ketidakmampuannya bekerja akibat tabrakan yang dialami. Demikian juga dengan sang penabrak, ia harus mendapatkan pidana penjara sehingga baginya untuk apa juga memberikan uang pengobatan kepada korban, ia sudah dipenjara. Dengan demikian pengenaan atau penjatuhan pidana penjara pada pelaku kejahatan berimbas kepada keluarga korban juga keluarga pelaku sendiri, dan tentu saja ini bukan sebuah solusi.

Cara pandang keadilan restoratif menuntut usaha kerja sama masyarakat dan pemerintah untuk menciptakan suatu lingkungan yang memungkinkan korban dan pelaku dapat melakukan rekonsiliasi konflik dan menyelesaikan kerugian mereka dan sekaligus menciptakan rasa aman dalam masyarakat. Dari paparan diatas maka kiranya ada pembaharuan terkait sistem peradilan pidana kita agar lebih memberikan perhatian akan nasib korban tindak kejahatan secara ekonomi dan psikologis, sehingga korban bisa mendapatkan kembali hak-haknya. ${ }^{14}$

Pergeseran konsep kejahatan dan orientasi hukum pidana telah membawa harapan cerah untuk perlindungan hukum terhadap korban, dan memberikan dampak positif bagi pencegahan dan penanggulangan kejahatan, yang bertujuan untuk mengurangi kejahatan dan memulihkan korban kejahatan serta pihak-pihak yang terlibat di dalamnya. ${ }^{15}$

\footnotetext{
${ }^{13}$ G. Widiartana, Op. Cit., hal. 106

14 http://tulisanulin.blogspot.com/2011/04/keadilan-restoraitf-bagi-korban-tindak.html, diunduh 12 April 2013, diunduh Jam 10.30 WIB

${ }^{15}$ Siswanto Sunarso, Op. Cit., hal 48
} 
Dengan berpijak pada keadilan restorative maka korban, pelaku dan masyarakat dapat mewujudkan :

a) Terciptanya rasa aman serta adanya tanggung jawab masyarakat terhadap kondisi social yang menjadi penyebab terjadinya kejahatan

b) Memperhatikan kebutuhan dan kepentingan korban sebagai bagian dari penyelesaian kejahatan

c) Mendorong terjadinya perdamaian antara korban dan pelaku, melalui mediasi, pertemuan, program perbaikan ekonomi, da pendidikan kejujuran

d) Orientasi keadilan ditujukan kepada orang yang melanggar haknya yang dilindungi oleh peraturan hukum (korban), yaitu orang-orang yang menderita langsung akibat kejahatan, masyarakat, negara dan pelanggar itu sendiri. ${ }^{16}$

\section{PENUTUP}

Keadilan restoratif merupakan bentuk pemulihan terhadap hak-hak korban kejahatan yang dilakukan secara rekonsiliasi, dimana pertanggungjawaban pelaku dapat dirumuskan sebagai dampak pemahaman serta bertujuan untuk membantu memutuskan mana yang paling baik bagi penyelesaian tindak pidana dengan mempertimbangkan penderitaan dan kerugian korban.

Merupakan perhatian dari penegak hukum dalam memproses suatu perkara pidana tidak hanya melihat satu sisi yakni pihak pelaku atau kepentingan pelaku, namun juga, kepentingan pihak korban, dan masyarakat yang tentunya lebih memberikan rasa keamanan, keadilan dan kepatian hukum di tengah-tengah masyarakat.

\footnotetext{
${ }^{16}$ Siswanto Sunarso, Ibid., hal.48
} 


\section{DAFTAR PUSTAKA}

Anonim. "Keadilan Restoratif Bagi Korban Tindak Pidana". [http://tulisanulin.blogspot.com/ 2011/04/keadilan-restoraitf-bagi-korbantindak.html], Diunduh pada tanggal 12 April 2013.

Dikdik M., Arief Mansur, dan Elisatris Gultom. Urgensi Perlindungan Korban Kejahatan Antara Norma Dan Realita. Rajawali Pers, Jakarta, 2007.

Hamzah, Andi. Hukum Acara Pidana Indonesia. Jakarta: Sinar Grafika, 2009.

Indonesia. Undang-Undang tentang Kitab Undang-Undang Hukum Acara Pidana. UU Nomor 8 Tahun 1981. LN Tahun 1981 Nomor 76, TLN Nomor 3209.

Marzuki, Peter Mahmud. Pengantar Ilmu Hukum. Jakarta: Kencana Prenada Media Group, 2008.

Prayitno, Kuat Puji. "Restorative Justice Untuk Peradilan Di Indonesia (Perspektif Yuridis Filosofis Dalam Penegakan Hukum In Concreto". Jurnal Dinamika Hukum, Vol. 12 No. 3 September 2012. Hal. 415-416

Sunarso, Siswanto. Viktimologi Dalam Sistim Peradilan Pidana. Jakarta: Sinar Grafika, 2012.

Susanto, I.S. Kriminologi. Yogyakarta: Genta Publishing, 2011.

Widiartana, G. Viktimologi Perspektif Korban Penanggulangan Kejahatan. Yogyakarta: Universitas Atmajaya Yogyakarta, 2009. 